\title{
From double tax avoidance to tax competition: explaining the institutional trajectory of international tax governance
}

\author{
Thomas Rixen \\ Social Science Research Center Berlin (WZB) \\ Reichpietschufer 50, 10785 Berlin, Germany \\ Phone: +49 - (0)30 - 25491293 \\ E-mail: rixen@wzb.eu
}

\begin{abstract}
This article presents a history of international tax governance and offers a rationalist reconstruction of its institutional trajectory. As an unintended consequence of its institutional setup, the tax regime, which originally only dealt with double tax avoidance, endogenously produces harmful tax competition. Despite this negative effect there are only incremental and partial changes of the regime, which are insufficient to curb tax competition. I argue that this development can be explained by considering the properties - and the sequence in which they come up - of the collective action problems inherent in double tax avoidance and tax competition. First, in double tax avoidance, a coordination game with a distributive conflict, governments did not want to endanger the solution they had institutionalized long before tax competition became virulent. Second, governments are unable to resolve the emergent asymmetric prisoner's dilemma of tax competition due to conflicts of interest among big and small country governments and successful lobbying of corporate capital. As a result, the institutional trajectory is characterized by the simultaneous occurrence of stability in the core principles and indirect and incremental changes of the rules in the form of rule stretching and layering.
\end{abstract}

\section{KEYWORDS}

Double taxation; tax competition; rational institutional design; historical institutionalism; OECD; tax havens. 
This is the story of the global tax regime, which carries the seeds of its own undermining, but nonetheless persists to this day. When it was created in the 1920s and 1930s the sole purpose of the international tax regime was to mitigate international double taxation so that governments could benefit from international economic liberalization. From the 1960s onwards, under-taxation — comprising the related phenomena of tax competition, tax evasion and tax avoidance-became a pressing issue. As I show below, under-taxation is an unintended consequence of the particular institutional design of double tax avoidance (DTA). Under-taxation has made it difficult for governments to maintain an efficient and equitable tax system. Despite detrimental consequences, the basic approach to avoiding double taxation and the core principles of the global tax regime have remained unchanged. Instead of eliminating the root causes of the regime's weakness, actors only mitigated some forms of under-taxation through indirect and incremental institutional reform. How can we explain the institutional persistence of the tax regime despite its shortcomings?

I provide a rationalist explanation for the simultaneous occurrence of (core) stability and (peripheral) incremental change. I argue that the trajectory of DTA institutions can be explained by considering the sequence in which the collective action problems inherent in international taxation (viz. double tax avoidance and under-taxation) occur. The undertaxation problem is the impetus behind efforts to reform the DTA regime; nevertheless, full adaptation of the system does not occur, and this for two reasons. First, the avoidance of double taxation is a coordination game with a distributive conflict. Therefore the process becomes self-reinforcing: actors do not wish to endanger the coordinating function of the regime that they had established long before under-taxation became virulent. Second, undertaxation is an asymmetric prisoner's dilemma (PD) which governments are unable to resolve because of conflicts of interest between big and small countries, and powerful business 
influences on these governments. Consequently, governments only achieve gradual, indirect and incomplete reforms of the system. Using the examples of transfer pricing guidelines and controlled foreign corporation (CFC) legislation, I show that actors engage in rule stretching in an effort to contain under-taxation while leaving the DTA regime's principles formally unchanged. Further, as the example of the OECD Project on Harmful Tax Practices shows, actors also layer additional institutions on top of the DTA regime to support its functioning.

The contribution of this article is threefold: First, it introduces the issue of DTA to international political economy (IPE). Thus far, IPE scholars have focused only on tax competition. Either they have investigated its effects on domestic tax systems (e.g. Ganghof, 2006; Garrett and Mitchell, 2001; Genschel, 2002; Swank and Steinmo, 2002; Hays, 2003; for a review of this literature, see Rixen, 2007), specific international policies against tax competition, such as the OECD Project On Harmful Tax Practices (Sharman, 2006; Webb, 2004) and the European Union’s Savings Tax Directive (e.g. Dehejia and Genschel, 1999; Holzinger, 2005), or they have considered the development of tax havens and their role in the global economy (e.g. Palan, 2003). Although it is a much older phenomenon, international cooperation to avoid double taxation has not received much attention in IPE. ${ }^{1}$

Second, this article's focus on the DTA regime yields an alternative understanding of tax competition. In the existing literature, tax competition is treated as a natural corollary to economic globalization and liberalization; it is assumed to be an exogenously given force; the focus is on its effects in terms of welfare, distribution or national policy autonomy. By contrast, the causes of tax competition, have received no attention. Of course, globalization is a necessary condition for tax competition but it is not a sufficient one. Whether there is tax competition and what form it takes crucially depends on the rules that determine the consequences for particular cross-border transactions. Thus, in order to understand the 
dynamics of tax competition, we must also consider the regulation of these transactions, codified in the international DTA regime. The strategic choices and opportunities of taxpayers and governments are shaped by the double tax regime, which thus provides the institutional foundation for tax competition. In this paper I show that tax competition is not exogenously given: its existence and the specific form it takes are the endogenous consequence of prior institutional choices by governments in the area of DTA.

Third, this article takes up recent calls to bring 'historical' or 'new' institutionalism—a theory which has found application primarily in domestic and comparative political scienceinto international relations (IR) (Zürn, et al., 2007; Fioretos, 2007). In IPE institutional change is often addressed from a constructivist perspective (see e.g. Broome and Seabrooke, 2007; Blyth, 2007). I show that issues of institutional dynamics and stasis can also be explained from a rationalist viewpoint and that it is worthwhile for scholars to supplement analyses based on interests and structure with historic institutionalisms' perspective on sequence and timing.

The rest of the paper is structured as follows. In the next section I develop the theoretical framework. In subsequent sections, I trace the historical record of the tax regime and show how my model can explain it. The second section focuses on the regime’s founding period from the 1920s to 1950s. The third section shows how the regime setup endogenously creates under-taxation and that, while actors could foresee this consequence, they decided not to address it at the onset but to wait until it became pressing. The fourth section analyzes the attempts to shore up the DTA regime against under-taxation. In the fifth section I consider alternative explanations. The conclusion provides a summary of my findings and a brief discussion of their implications for future research. 


\section{A SIMPLE MODEL OF INSTITUTIONAL DESIGN AND DEVELOPMENT}

In this section, I introduce a simple sequential game theoretic model to explain the institutional trajectory of the double tax regime. The twin problems of international taxation—namely, double taxation and under-taxation-are represented by two different strategic structures, which have been tackled sequentially, rather than simultaneously. Only after the problem of double taxation had been solved, did the problem of under-taxation become relevant. This is so because it is only worthwhile for individuals and enterprises to engage in trans-border investment if DTA is in place. Avoiding double taxation is part of the liberalization of the international economy and this is a necessary condition for international under-taxation to arise. In the following, I derive the strategic structures of both problems, and then consider the resultant expectations for institutional design and its development over time.

\section{The strategic structures of double taxation and under-taxation}

To determine the strategic structure of an issue area requires careful analysis of the underlying problem and the relevant actors' interests. Spatial constraints allow me here only to provide a discussion of the basic intuitions. A complete overview and derivation can be found in Rixen (2008, 30-54 and 156-161). ${ }^{2}$

The simple game theoretic model is sequential in that it considers the strategic structures at two different stages in a process. I focus on the strategic international interactions of governments, which I derive on the basis of two assumptions. First, all governments set their international tax policies with the aim of maximizing national welfare under the constraint of having to obtain domestic political support for their policies. Domestic political support is operationalized by considering the positions and the political influence of three societal interest groups: (a) labour, (b) individual capital, i.e. private citizens with savings and 
portfolio investment income, and (c) corporate capital. These are small groups in Olson's (1965) sense, which may exert more political influence than the big, diffuse group of the general population. Such interest groups can divert governmental policy away from maximization of national welfare. Second, maximizing national welfare can mean different policies for big and small country governments (e.g. Bucovetsky, 1991); therefore I differentiate between these two types.

At the beginning of the first stage, international investment is subject to double taxation because all countries exert their right to tax to the full. Double taxation results from an overlap of jurisdiction to tax between a residence state, where a recipient of income lives, and a source state, where that recipient's income was generated. Double taxation hampers transborder economic activities; domestic investment is favoured over international investment (e.g. Musgrave, 2006). Since there are collective gains to be made from liberalizing, big and small country governments alike, in their capacity as residence countries, have a collective interest in avoiding double taxation. Further, it can be shown that governments also have an individual interest in providing double tax relief, irrespective of whether other governments do so. Double tax relief is a coordination game. Empirically this is evidenced by the fact that all governments provide unilateral tax relief on foreign source income.

Given that residence country governments provide unilateral tax relief, there are still concerns over the distribution of tax revenues and other economic benefits. Whereas adopting unilateral relief is always preferred to not alleviating double taxation, doing so leaves tax revenue to the source country, where the residence country's investors face a considerable tax burden. Thus the residence country achieves only its second-best outcome: it would be better off, if double taxation were avoided and if it had the right to tax. Given its willingness to grant double tax relief unilaterally, the residence country has an incentive to limit the taxation rights 
of the source country. A lower source tax would reduce the tax burden of its investors abroad and, given that it employs the credit or deduction method to avoid double taxation, it can collect the residual taxes on the foreign income without raising the overall tax burden on international investment. The interests of the source country are just the opposite: it favors higher source taxes. Note that all countries are residence and source countries at the same time, but to different degrees. Consequently, their distributive interests will be determined by their relative investment positions: net capital importers have strong source interests, whereas net capital exporters will have residence interests. Many big countries are net capital exporters, whereas small countries are often net capital importers. Overall, the structure of the 'double tax avoidance game’ is that of a coordination game with a distributive conflict. ${ }^{3}$

Apart from the fact that double tax avoidance maximizes national welfare, it is also in line with considerations of domestic political support. None of the three domestic pressure groups would oppose this policy: labor is not interested in double taxing international capital, as long as enough tax is paid at home; both individual and corporate capital certainly favor double tax avoidance and are indifferent as to where they are liable to pay the (remaining) $\operatorname{tax}^{4}$

Once double taxation is avoided, the situation should be one of single taxation: just like domestic investment, international investment is only taxed once. However, the liberalizing effect of double tax avoidance makes it difficult to sustain this situation. When international investment is free to move across borders, taxpayers can shop between jurisdictions for the lowest taxes. In the second stage of the game, countries can benefit individually from undercutting each other's taxes to attract foreign capital. The result of this tax competition should be a race to the bottom in taxes. For big country governments, since their domestic tax base is relatively large compared to the attracted foreign tax base, this implies national 
welfare losses. It is collectively preferable for them to come to a cooperative agreement to curb tax competition. For small country governments, the situation is different. Since their domestic tax base is small compared to the foreign tax base they can overcompensate the potential welfare loss of lower taxes with the inflow of tax base from other countries (Bucovetsky, 1991). Thus, small countries oppose collective agreements to abolish undertaxation. In effect, this means that big countries — if they manage to overcome the dilemma posed by their conflicting individual incentives to continue undercutting one another-would either have to provide side payments to tax havens (which are always small countries) or somehow use their power to force them into compliance with such an agreement. The strategic structure is that of an asymmetric prisoner's dilemma. Overcoming an asymmetric dilemma is demanding because of the strong conflicts of interest and the individual incentives to defect from a cooperative solution.

This pessimistic view is reinforced by domestic politics: In a first take, one would expect individual and corporate capital to oppose a government's ambition to come to a collective agreement curbing tax competition with other governments; and labour to oppose tax competition and support measures against it because it leads to an increase of the tax burden on labour relative to capital (Schwarz, 2007). The outcome would thus depend on whether the government leans to the left or right. These initial assumptions about the interests of big country governments and societal interest groups must, however, be qualified in light of the differentiation between two types of tax competition. Under real tax competition governments compete for the attraction of real economic activity, i.e. production facilities. In contrast, virtual tax competition for so-called paper profits is about the mere assignment of income, irrespective of where it was actually produced. This kind of tax competition is enabled by the particular solution adopted to avoid double taxation and accounts for a significant part of real- 
world tax competition. The two types of tax competition are not independent of each other. As long as multinational enterprises (MNE) can shift paper profits out of high tax countries, they will not have to relocate real economic activity in order to gain tax savings. If the possibilities for profit shifting are closed, then real tax competition may intensify and MNEs may relocate 'real' production facilities and jobs (Keen, 2001).

How relevant the substitution between real and virtual tax competition will be is a contested empirical issue that depends on the tax elasticity of real investment. The majority of studies expect a sizable effect (de Mooij and Ederveen, 2008), so big country governments may be rightfully hesitant to curb corporate profit shifting, for fear of a reduction in national welfare due to job and real investment losses. ${ }^{5}$ In any event, the threat of real dislocation alone should increase corporate capital's influence on governmental policies. Further, labour may not be an unambiguous supporter of preventing corporate profit shifting, unless it is combined with an effective policy to also curb, or to at least dampen, real tax competition.

In the case of virtual tax competition for individual capital income, this is different. Competition is effected by offering concealment services (bank secrecy rules or legal vehicles such as trusts) to individuals so that they can shelter their income in tax havens while continuing to live in high tax countries. Policies to prevent this should find unambiguous support from labour, because job loss is not to be feared. Corporate capital should be indifferent. But although such measures run contrary to the interests of individual capital, this group would probably not oppose them vocally, because not reporting foreign income in their home countries is illegal. Thus the political chances of preventing individual free riding (living in a country but evading its taxes) are much better than for curbing corporate free riding (producing in a country but avoiding its taxes). 


\section{$\underline{\text { Hypotheses on institutional design and development }}$}

From the foregoing discussion we can derive theoretical expectations on the institutional design of the DTA regime and its evolution in the second stage, once the problem of undertaxation emerges. From a perspective that considers sequence, governments first solve the DTA coordination problem. In coordination games actors have no incentive to deviate from an equilibrium once they have settled on it. According to standard predictions of rational institutional design there should thus be no need for enforcement institutions to monitor compliance and sanction non-compliance. But institutions can help actors to select among multiple possible equilibria over which they have conflicting distributive interests. This will be the case if there is no salient solution on which actors are likely to settle. In issue areas characterized by coordination problems we expect to find institutions that provide a focal point for actors, by generating and disseminating information and non-binding standards, designed to help them settle on one of the available equilibria (see e.g. Koremenos, et al., 2001: 787-8). Moreover, we expect powerful actors to have a strong influence on the choice of the standard (Krasner, 1991). Binding rules do not necessarily have to be multilateral: they are more likely to be bilateral or unilateral (cf. Snidal, 1985, 923).

As shown below, the problem of under-taxation is endogenously created by DTA institutions. In the second stage, therefore, we should expect the DTA regime to adapt its institutions to this problem. Because enforcement mechanisms are needed to overcome an asymmetric PD, the DTA regime ought to develop monitoring capacity and punish those who under-tax. Moreover, it ought to establish binding multilateral rules. Only if the regime encompasses all countries would it be impossible for any government to free ride and exploit those abstaining from under-taxation (e.g. Dehejia and Genschel, 1999; Holzinger, 2005). 
But theory predicts that institutional adaptation is neither instantaneous nor complete. It is hampered by severe institutional rigidity. Institutions designed to cater to problems of coordination may be quite inert. Generally, coordination regimes are stable because of the underlying incentive structure which makes it individually rational to follow the convention once it has been established. This can lead to a regime's inflexibility in responding to external shocks. In the extreme, a coordination regime may become 'dysfunctionally stable' (Snidal, 1985: 939). Due to sunk costs incurred by bargaining over the creation of a focal point, actors may shy away from searching for a new convention (Pierson, 2004: 143-4). Because of strong conflicts of interest, it can be difficult for governments to find the required cooperative solution. The above discussion suggests two additional reasons, why reforming the tax regime might not succeed: small tax havens will resist reform efforts and big country governments will hesitate vis-à-vis corporate profit shifting, as a response to domestic political pressure from corporate capital.

Overall these considerations lead us to expect that reform efforts will be in the direction of multilateralism and better enforcement as a response to under-taxation. Due to systemic rigidity, however, change will only be incremental and partial, and unlikely to represent an effective solution to under-taxation.

Beyond the general prediction that institutional adaptation will be partial and incremental, I am also interested in the trajectory of institutional adaptation. While there is little deductive knowledge on historical institutional development (Pierson, 2004: 139), different logics of incremental change can be inferred from case studies literature. Two possible logics are relevant in the case of the double tax regime: ‘layering' and 'conversion’ (Thelen, 2003: 22630; Streeck and Thelen 2005). In the first of these modes of institutional change, a new arrangement is layered on top of an existing one. Institutional entrepreneurs may lack the 
capabilities to reform an institution directly; therefore, actors have an incentive to work around the existing institution in order to exact at least some kind of change. The actors do not try to dismantle or transform the existing institution directly; nor do they push developments further along the same institutional trajectory, as path dependency arguments suggest. Rather, they attempt to bypass the existing arrangement and in so doing will slowly and indirectly affect its institutional trajectory. Depending on the goals of the designers of the layered institution, an existing institution may receive external support or it may gradually be subverted.

In the second logic of incremental change, 'conversion', the general idea is that an institution which was designed to pursue one set of goals is redirected to a different set of goals. Such processes can be generated by external pressures which lead actors to use existing arrangements in new ways and for different purposes. Over time, the institution fulfils other or additional functions rather than just those to which it was initially assigned, but its basic setup remains unchanged.

In the next three sections I will provide an account of the tax regime's founding and its trajectory and show that it can be explained by the theoretical framework just outlined.

\section{'ERADICATING THE EVILS OF DOUBLE TAXATION'}

In this section I describe the DTA regime's establishment in the 1920s and its growth and firm institutionalization since the 1960s. I will show that the institutional design reflects the functional requirements of a coordination game with a distributive conflict.

\section{The founding period: 1920 to 1945}

The original and initially sole purpose of the global tax regime was to mitigate international double taxation in order to liberalize international trade and investment. In 1918 
the United States introduced the foreign tax credit that foresaw unilateral tax relief on foreign source income. Other countries followed suit in consecutive years. ${ }^{6}$ Parallel to this development the League of Nations, in response to demands by the International Chamber of Commerce, proposed a collective effort to find a coordinative solution to the problem of overlapping tax jurisdictions. The League appointed economists to address the issue and convened several conferences of technical experts and government officials (League of Nations, 1923). What became apparent was that both the source and residence principles were justifiable on specific grounds. Emphasizing individual fairness implies that the residence principle should be accorded more weight, because it is more conducive to basing taxes on the ability to pay. On the other hand, the consideration that the source country provides the infrastructure which allows the generation of income in the first place leads to a preference for source taxation. According to the so-called benefit principle, taxes are the price for the public goods used to produce private profit. Both of these arguments are simple and intuitive. None of the scholars who have addressed the allocation of taxing rights have exclusively favoured one or the other; the general preference is for a solution which accords different weights to each (a brief and accessible overview of the continuing debate is contained in Li, 2003: 4957).

In the political debates, these normative issues mingled with distributive conflicts between capital importers and exporters - the former favouring the source principle and the latter the residence principle—since the respective solution would give each a bigger share of the international tax base (see e.g. Dagan, 2000). To make a long story short the solution that emerged represents a compromise between both principles on a case-by-case basis. Broadly speaking the primary (or exclusive) right to tax active business income is granted to the 
source country; the residence country, by contrast, has the primary (or exclusive) right to tax passive income, i.e. interest, dividends or royalties (see e.g. Avi-Yonah, 2006).

\section{$\underline{\text { Sovereignty-preserving legal constructs }}$}

In order to institutionalize this compromise solution, a series of increasingly elaborated non-binding model conventions (MCs) were drafted, which could be used as templates for bilateral double tax treaties (DTTs). The MC refers to a series of legal constructs establishing a nexus between the transnational tax base and a country (Bird and Wilkie, 2000: 91-5). For example, the concept of a permanent establishment (PE) codifies what is taxable as a separate entity of an MNE in the source country. The important point about this and other constructs, still in use today, is that internationally defined rules are kept to a minimum. The MC and the bilateral treaties based on it provide general guidelines (although these can be quite complex in order to ensure universal applicability) about the nexus between a person or an entity and the respective jurisdiction. Bilateral DTTs achieve no more (nor less) than disentangling the transnational tax base and assigning it to different jurisdictions. Once the jurisdiction to tax has been established, a country is then free to apply its own national tax law to its share of the income. This approach is not aimed at harmonizing national tax laws; the internal qualities of national tax systems are not subject to the regime rules. The DTA regime merely regulates the

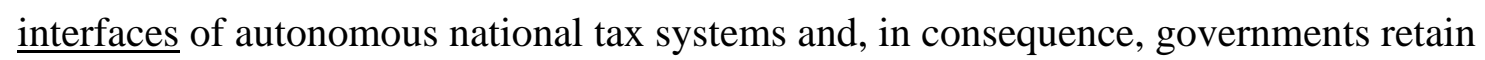
almost unlimited sovereignty over their share of the transnational tax base (Li, 2003: 31; Vann, 1991: 102).

Emblematic for this are the rules for allocating expenses and profits among different parts of an MNE. According to the separate entity approach foreign branches or subsidiaries are to be taxed as if they were independent market participants, exchanging goods and services at arm’s length prices (Eden, 1998: 32-52). Another sovereignty-preserving approach is the use 
of exemption systems or credit systems with deferral: income taxed at source is not subject to taxation in the home country upon accrual. Even if a foreign business is beneficially owned by a resident, e.g. a subsidiary of an MNE, the home country will not tax the income of this entity until it is repatriated. This illustrates mutual respect for the territorial integrity of differing national tax systems, characteristic for the tax regime (Graetz, 2003: 217-9).

\section{Institutional entrenchment of the DTA regime}

In its early period the practical relevance of the DTA regime was limited. Although the 1920s saw a brief revival of open international capital markets (Helleiner, 1994: 26-7), ending with the Great Depression, the level of trans-border investment and MNE activities remained low well into the 1960s (Bordo, et al., 1999: 11, 62). Direct taxes were only introduced after World War I and tax burdens were still comparatively modest (see e.g. Webber and Wildavsky, 1986: 436-45); accordingly, transnational tax revenues at stake were also low. Thus, while the basic principles were established by the League of Nations in the 1920s and early 1930s, the regime remained largely dormant. In 1928, thirty-five DTAs were in force. ${ }^{7}$ In the 1950s the regime was still of limited practical significance. While the bilateral treaty network grew (from 108 in 1948 to 263 in 1958), the number of DTAs in force was still low.

After World War II, the OECD replaced the League of Nations and briefly the United Nations as the main multilateral policy forum for discussion of international tax issues. From 1956 to the early 1960’s the OECD’s Committee on Fiscal Affairs (CFA), made up of government officials and tax experts, integrated and consolidated the prior versions of the MC. This firmly institutionalized the non-binding convention as the basis for bilateral treaty negotiations. The principles and norms of the tax treaty regime had come to full fruition.

Since the 1960s the network of DTAs has grown continuously. In particular since the mid-1980s international investment has increased steeply. Much of this economic 
internationalization has occurred within transnational business structures. In 1970 there were about 7,000 MNEs. From 1990 to 1998 the number increased from 35,000 to 53,607. By 2006 there were 78,000 parent companies with at least 780,000 affiliates. Intra-firm trade increased from an estimated one-third of overall trade in 1998 to 60 per cent today (United Nations, various years). This means that the overall tax base subjected to the DTA regime rules has grown. At the same time the tax burden (measured as a percentage of GDP) in OECD countries has increased steadily, as is evidenced by a rise in the average tax ratio from 21 per cent in 1963 to 35.7 per cent in 1993. Since then it has remained stable, reaching 35.8 per cent in 2007 (OECD, 2009a).

The DTA regime has thus gained in practical importance. More than 2000 bilateral tax treaties, connecting about 180 countries, are in force today. Cooperation within the OECD has intensified, reflecting this increased importance. The CFA continually engages in technical elaboration and adaptation of the model. Today the MC is published in an ambulatory format, with consolidated versions appearing every two to three years (OECD, 2008: Introduction, para. 11). Essentially all DTTs are based on the model. The OECD MC represents the general consensus on international taxation; its principles, norms and rules also effectively constrain the policies that countries can pursue unilaterally vis-à-vis foreign tax revenues (Avi-Yonah, 2006). Although the rules have become more sophisticated and complex over time, the basic principles and mechanisms of sovereignty preservation that emerged in the 1920s have remained unchanged (Graetz, 2001: 262-71).

\section{The design of a coordination regime}

The setup of the DTA regime is in line with theoretical expectations of institutional design in coordination games. The OECD does not have the power to enforce compliance with DTA rules. Instead it provides governments with information, most importantly the non- 
binding MC, which serves as a focal point in bilateral distributive bargains and has become the accepted standard for binding DTTs and domestic rules on the taxation of international income (Rixen 2010).

Powerful governments and societal interests also behave in accordance with theoretical expectations. The USA, as the hegemonial power, was central in setting the standard by being the first country to grant a foreign tax credit. The importance of powerful actors is further evidenced by the fact that the OECD — the 'rich countries' club' — became the standard setter. The UN which devotes fewer resources and expertise to issues of international taxation has not been able to maintain its leading position. While the UN also produces an MC for bilateral DTTs (United Nations, 2001), its MC generally reproduces all the basic provisions of the OECD MC. ${ }^{8}$ Capital interests, as predicted, favour the avoidance of double taxation; this is evidenced by the fact that the International Chamber of Commerce put the issue on the agenda in the first place. Also, as predicted, there has been no opposition from labour to these developments.

\section{UNDER-TAXATION AS AN UNINTENDED CONSEQUENCE}

In this section I show that the particular approach to double tax avoidance engenders under-taxation and that, while governments foresaw the problem, they did not address it in the regime’s founding period.

\section{The endogenous creation of harmful tax competition}

The effective removal of tax obstacles and other liberalizing policies have induced increased mobility of capital. Since the 1960s taxpayers have begun to take ever greater advantage of the differing national tax laws by making sure that their income is taxable in low-tax countries. 
Such tax planning need not involve the relocation of economic hardware like direct investments or jobs; it can be achieved through the shifting of paper profits. One of the most common methods of tax planning is to set intra-company cross-border transfer prices so that income is shifted to a low-tax country and expenses to a high-tax country. The diversion of profits to low-tax countries often involves CFCs—corporations owned wholly, or to a significant extent, by non-residents of a low-tax country. Income can be retained in these entities in order to make use of deferral and gain tax benefits. Setting up such 'letterbox' companies is attractive because they enable taxpayers to establish residence in one country and ensure that their income is taxable in the respective low-tax country. CFCs also play a role in so-called treaty shopping. Instead of retaining income in a base company, the CFC is used as a pass-through entity to reap the benefits of a DTA to which one otherwise would not have access (see Arnold and McIntyre, 1995: 8-17). These and other tax planning schemes channel income into jurisdictions with only an artificial connection to the real economic activity that should be the target of taxation.

Taxpayers’ ability to shift profits and losses creates tax competition, in which small and big countries have divergent interests. Tax havens—always small countries—are the winners of tax competition. In fact, being a tax haven implies a country's willingness to create a tax system geared towards the needs of foreign taxpayers. Tax havens use tax sovereignty not to impose taxes on their legitimate share of the transnational tax base, but rather to 'poach' the tax bases of other countries (Palan, 2003). Some tax havens specializing completely in offshore activities adopted this status as an economic development strategy. They are in a position of 'provocative dependence' (Hampton and Christensen, 2003); they need the offshore sector for economic survival, but they are also viewed as 'renegade states' (Eden and Kudrle, 2005) by so-called high-tax nations. To compete for the transnational tax base, havens 
specialize in different tax planning activities. ${ }^{9}$ Empirical evidence shows that their operations are profitable (Hines, 2005).

Big countries are the losers of tax competition. The Tax Justice Network (TJN, 2005) estimates that 11.5 trillion US dollars are hidden in tax havens, indicating a yearly revenue loss for high-tax countries of about 255 billion US dollars. The ever-present threat of tax base erosion must also be taken into consideration in the design of national tax systems. The general trend in corporate taxation in reaction to tax competition is a policy of 'tax cut cum base-broadening'. While this response has been successful insofar as on average there has been hardly any loss in general tax revenue over the last fifteen years, it negatively impacts on the structure of national tax systems. Big and highly profitable MNEs enjoy tax relief, while small and medium-sized companies are taxed more heavily. Tax burdens are shifted from capital income to labour income and consumption (Loretz, 2008; Schwarz, 2007). In addition, lowering nominal corporate tax rates undermines the progressivity of personal income taxes because corporate tax serves as a backstop for personal income tax (Ganghof, 2006).

Profit shifting and tax arbitrage are only possible because countries rely on a sovereigntypreserving approach to international taxation. Only because every government is free to design its own rules of national taxation can some letterbox company in a tax haven be treated as an independent entity for which the government is free to levy a national tax rate of zero. In addition, many of the techniques of tax avoidance rely directly on the legal constructs laid down in the regime. The manipulation of transfer prices under the ALS is an example. The application of the ALS is difficult and gives firms the opportunity to minimize taxes because comparable, uncontrolled prices, agreed on by independent market participants, are often hard to find. This problem is particularly pronounced in the case of intangible assets. Ironically, MNEs exist because of the absence or imperfections of an arm's length market, yet the ALS 
is used to determine transfer prices for tax purposes (Eden, 1998: 565). If different branches of one company are treated as if they were separate entities, then there is a natural incentive for MNEs to use this leeway. While the rules deny the 'unity of the subject', the real subjects remain whole and 'take advantage of the fiction of their fragmentation' (Palan, 2003: 105, 108).

The fundamental problem with the sovereignty-preserving approach is that transnational tax bases are not givens that sit still and wait to be carved up between national tax authorities: rather, tax bases are endogenous to the rules themselves. Taxpayers, individual and corporate, can structure their cross-border activities such that — given the regime’s sharing rules — they can minimize their tax payments. While many of the decisions to abandon capital controls, lower trade barriers and other policies of liberalization that enhance the international mobility of tax bases were taken outside the tax treaty regime, this is only a necessary but not sufficient condition for under-taxation. The possibilities for tax evasion and avoidance arise only in combination with the sovereignty-preserving design of the institutions of double tax avoidance. The DTA regime provides the institutional foundation of tax competition.

\section{Under-taxation as secondary problem}

Was this unintended consequence unanticipated? Did decision-makers at the time not foresee that the avoidance of under-taxation in a sovereignty-preserving way would create the problem of tax arbitrage? Two episodes from the regime's founding period show that the problem of under-taxation was foreseen but considered to be of secondary importance relative to the avoidance of double taxation.

In their deliberations at the League of Nations, delegates actually addressed the issue of tax evasion and avoidance. The concern was that the co-existence of different national tax systems and the removal of obstacles to international capital flows would increasingly enable 
capital flight. A commissioned group of experts argued that a functionally adequate response to the problem of evasion and avoidance must be multilateral; otherwise there would be capital flight to those countries not party to the agreement (League of Nations, 1925: 24-6). But most member states were not willing to subscribe to such a solution. Beyond the fact that some states were not willing to engage in information exchange at all (see e.g. the Swiss position: League of Nations, 1928: 14-5), they generally cautioned that the 'disadvantage of placing any obstacles in the way of the international circulation of capital, which is one of the conditions of public prosperity and world economic reconstruction’, should be carefully weighed against the goal of fighting tax evasion (League of Nations, 1927: 5). Measures against evasion should be premised on effective double tax relief (see e.g. the position of Sweden: League of Nations, 1928: 14). ${ }^{10}$

In the 1930s the issue re-emerged and a draft multilateral agreement on the exchange of information was produced. But '[g]overnments showed reluctance to change their domestic legislation merely to meet the requirements of foreign administrations, and they were unwilling to ask their nationals to supply information not needed for domestic purposes’. Furthermore they were unwilling to help other countries 'enforce their respective tax laws unless [these countries] first agree[d] to remove the inequitable burden that results from double taxation'. The conclusion was that the appropriate way to deal with evasion and avoidance was to include provisions (generally limited in scope) on the exchange of information in bilateral double tax treaties. Further, the fight against evasion and avoidance was regarded as the responsibility of national tax authorities (Carroll, 1939: 36-7).

Considerations about under-taxation were also deferred when opting for separate entity accounting on the basis of the ALS. In principle there are three methods for taxing MNEs. First, transnational economic activity could be taxed internationally—governments would 
agree on a common tax base, a common tax rate and a common system of tax administration. An international business tax would imply the delegation of taxation power to an international authority. A second option would be the one that has actually emerged. This solution lies at the other end of the spectrum; it is sovereignty-preserving. Third, there is also an intermediate option: MNEs could be subjected to unitary taxation with formula apportionment (UT+FA). An MNE's profit is determined through a combined report and then allocated to each part of the enterprise on the basis of a predetermined formula. The formula should reflect the true economic contributions of each branch, e.g. by referring to factors such as property, sales and payroll. This system would require governments to share their sovereignty with respect to the definition of the tax base but it would leave them free to apply their own preferred tax rate. UT+FA is seen by most tax experts as a way to curb profit shifting from high-tax to low-tax countries (Arnold and McIntyre, 1995, 66-7).

The first option has never been contemplated and is generally believed to be unattainable on a global scale. The intermediate option, $\mathrm{UT}+\mathrm{FA}$, did receive serious consideration in the development of the international tax regime. Although the 1920s discourse reflected a slight preference for formula apportionment, the mood had changed by the 1930s. On the basis of a study of 35 federal tax systems, the so-called Carroll Report (League of Nations, 1933), the League’s Fiscal Committee came to adopt the allocation convention of 1935, which recommended separate entity accounting based on the ALS. The Carroll Report was later criticized for understating the extent to which formula apportionment methods were actually in use-e.g. in Spain, Switzerland and some US states - in order to strengthen the case for the solution that was actually preferred by the United States (Langbein, 1986: 632-4).

The crucial point here is that formula apportionment and separate entity accounting were seriously considered as potential solutions at the time, and it was recognized that the 
indeterminacy of arm's length transfer pricing creates leeway for tax minimization (Graetz, 2003, 403-407). Ultimately, however, governments were unwilling to agree on UT+FA and thus openly address the distributive conflict over the allocation of the tax base. The ALS was perceived as a solution capable of de-politicizing this conflict (Picciotto, 1992: 172). The provisions of the allocation convention are still the essence of today's transfer pricing rules.

That the problem of under-taxation was acknowledged is evidenced by the fact that tax administrations may correct the transfer prices set by businesses by using 'fractional methods', i.e. formula apportionment, for those cases where the ALS yields indeterminate results (Wang, 1945: 77-81). Since it was considered impossible to come to agreement on a general formula, profit shifting was to be tackled case-by-case through cooperation among national administrations whenever difficulties arose (Picciotto, 1992: 183-5). What governments could not foresee was that the sheer magnitude of multinational activity and the increasing importance of intangible assets overburden tax administrations' capacities of effective enforcement.

Thus, while policymakers did foresee that taxpayers could more easily engage in tax avoidance and evasion in an international economic environment, this problem was not given priority. It was feared that restrictive measures would harm efforts to liberalize trade and investment — the primary objective at the time of the regime's establishment.

\section{INSTITUTIONAL REACTIONS TO THE PROBLEM OF UNDER-TAXATION}

The second period is characterized by efforts to reform the DTA regime by preventing under-taxation which had become a pressing problem from the 1960s onwards. Governments tried indirect reform by devising unilateral anti-avoidance rules and actively diffusing them to other OECD countries. Another indirect measure was the modernization of the ALS in the 
1980s and 1990s. From the mid-1990s on, with the problem having come to full blossom, reform efforts became more determined as evidenced by the OECD project on harmful tax practices. Ultimately, however, these attempted reforms have led only to incremental change, leaving the basic institutional setup unchanged.

\section{The 'subliminal' transformation of the DTA regime}

While there are various unilateral anti-avoidance measures like thin capitalization rules and anti-treaty shopping provisions (for a brief overview see Arnold and McIntyre, 1995: 6988), a particularly prominent case is the introduction of CFC legislation. In the 1960s the USA under President Kennedy was the first country to introduce comprehensive CFC legislation. CFC rules are aimed at the use of foreign subsidiaries as base or conduit companies in tax haven countries, which serve no substantive economic purpose but the taxprivileged holding of assets for the group. Resident shareholders controlling a subsidiary in a tax haven are taxable on the income of that subsidiary in the current period, whether or not the income is actually distributed to them. Thus, CFC rules pierce the 'corporate veil' of the tax haven entity and violate the principle of separate entity accounting.

CFC rules were contested domestically. US businesses and the Republican opposition in Congress argued that American MNEs would suffer a competitive disadvantage vis-à-vis their foreign competitors who could continue to shelter their income from taxation. As a compromise solution the rules that were finally implemented singled out a particular type of income likely to be diverted to tax havens, namely passive income (Engel, 2001: 1527-8). The USA promoted this legislation within the OECD. In 1987 the OECD suggested that unilateral anti-avoidance measures be introduced in all of its member countries and that the effectiveness of these measures be supported through increased multilateral information exchange (Eden and Kudrle, 2005: 115-7). Today nearly all major capital exporting nations 
have passed similar legislation. In the process, all have experienced opposition from corporate capital claiming that too strict rules would endanger a country's competitiveness (Picciotto, 1992: 144-6).

Tax havens also opposed these measures initially, arguing that CFC rules infringed on their right to determine the tax treatment of the relevant income at source. Anti-avoidance measures could lead to double taxation, since both residence and source state claimed the right to tax the same income and thus violated tax treaties and the general principles of the tax regime. The response of the OECD and high-tax countries relied on the notion of the 'deemed dividend'. Instead of viewing the holdings of a CFC in a tax haven as profit, more correctly these holdings could be viewed as the income of the shareholder (the resident of the high-tax country). Thus CFC rules would not interfere with a tax haven's sovereignty nor would they constitute double taxation because the income in question rightfully belongs to the residence country. This interpretation has clearly become the dominant one (Avi-Yonah, 2006: 5-6). Today there is an implicit consensus that CFC rules are a legitimate instrument for 'pushing the boundaries’ (Sandler, 1994) of the territorial limits to residence taxation.

Another area where incremental reform can be observed is transfer pricing. Countries have generally opted for separate entity accounting implemented through various national transfer pricing rules closely following the OECD guidelines (OECD, 2009b). With the multinationalization of production and the rising importance of intangibles—-trademarks, patents and other intellectual property—the ALS has come under pressure. In practice tax administrators have often relied on a combination of determining comparable, uncontrolled prices and profit apportionment. Thus the reality of transfer pricing is actually closer to unitary taxation than the rhetorical emphasis on the ALS would have one believe (Langbein, 1986; Bird and Wilkie, 2000: 92). 
In the 1980s the USA planned to reform national transfer pricing regulations so that the profit comparison would be explicitly recommended. The motivation for this unilateral move was that the US government was concerned with two related problems: namely, that US MNEs were shifting profits abroad by underreporting prices charged for trademarks and other intellectual property to their overseas manufacturing subsidiaries; and that foreign MNEsespecially from Japan—were overpricing imports to their American subsidiaries in order to lower their American tax bill (Webb, 2001: 137-40). ${ }^{11}$

The OECD and foreign governments opposed these proposed changes, arguing that they were inconsistent with the ALS and would violate a longstanding principle of the DTA regime, endangering its coordinative function. Subsequently, in a process of mutual adjustment, both sides reached a compromise: the United States reduced its emphasis on profit methods, agreeing to so-called 'transactional profit methods' (OECD, 2009b: para. 3.1); the OECD interpreted these methods as being in line with the traditional ALS (Radaelli, 1998; Webb, 2001). Overall the new guidelines have moved the actual rules closer to how transfer pricing had already been done in practice, but have taken great care to formally reinforce the principle of separate entity accounting. With the introduction of advanced pricing agreements (APAs) in many countries and their promotion by the OECD (OECD, 2009b: AN-22: para. 10), this trend has become more pronounced. APAs are mechanisms under which MNEs and tax administrations can bargain over the appropriate method of arriving at reasonable transfer prices and thus commit to certain prices before the transactions actually take place. Some have argued that APAs are only a secret method of applying formula apportionment on a case-by-case basis (US Senator Dorgan, cited after Célestin, 2000: 130).

The introduction of CFC rules and the attempts to reform the ALS aim at functional conversion. The reinterpretation of the fundamental building blocks of the DTA regime had 
the goal of moving closer to taxing different entities of a multinational group in a more consolidated fashion than was acceptable under the traditional understanding. In both cases the results were merely incremental changes to the original concepts. Actors took great care to subsume the new understandings under the traditional notions, exercising what can be termed rule stretching.

\section{The OECD's Project on Harmful Tax Practices: a more radical approach?}

Unilateral anti-avoidance rules are very complex but not very effective. What can be observed in practice is a proliferation spiral. States must continually amend their unilateral rules to react to new tax planning schemes. ${ }^{12}$ In 1996, recognizing this lack of effectiveness, the G-7 Finance Ministers mandated the OECD to launch a project to counteract 'harmful tax competition’ (OECD, 1998). The original purpose was to persuade tax havens to abolish harmful tax practices. In particular, they were encouraged to change their national tax laws so that it was no longer possible for a tax avoider to merely 'book' some economic activity in the respective haven without any underlying 'real' economic activity. In addition to that the project also aimed at so-called preferential tax regimes in high-tax countries, i.e. rules which tried to attract foreign capital by offering better treatment than was available to domestic investors.

Tax havens questioned the legitimacy of these requests by dismissing them as undue interference with their national tax sovereignty (Sharman, 2006: 83-86). In 2001, after fierce lobbying by corporate interests (see Ring, 2008: 24-32), the new US administration under George W. Bush declared that 'The United States does not support efforts to dictate to any country what its own tax rates or tax system should be, and will not participate in any initiative to harmonize world tax systems’ (O'Neill, 2001). While the project had originally challenged the notion of tax sovereignty—governments were asked to change their national 
tax systems - it now merely pushes for more transparency and better information exchange between tax havens and non-haven countries (OECD, 2001; 2004). Importantly, with this decision, the issue of corporate tax avoidance was off the agenda. More transparency and better information exchange only target tax evasion by individuals (Webb, 2004, 816).

The OECD began a process of evaluating the transparency of 82 financial centres. Tax havens are asked to meet certain requirements of transparency in their financial and tax systems and conclude bilateral information exchange agreements with other countries on the basis of a non-binding model convention (OECD, 2002). In the aftermath of the financial crisis 2008 the project experienced an additional boost by the G-20, which were eager to show more resolve in the fight against tax havens. In the process, a new black list of uncooperative jurisdictions was drawn up and the pressure to conclude bilateral TIEAs was increased. So far, 228 agreements have been concluded. ${ }^{13}$ With this reformulation of the project it fits quite well into the pattern of older initiatives to ameliorate information exchange, e.g. the multilateral ‘Convention on Mutual Administrative Assistance in Tax Matters’ (Council of Europe and OECD, 2003) which has been ratified by thirteen countries so far.

The project against harmful tax practices is an effort at layering. The results are meagre. Bilateral information exchange upon request is insufficient to effectively curb tax evasion; what is needed is multilateral automatic exchange (e.g. Sullivan, 2007). Nevertheless, the OECD project is remarkable in that for the first time in the history of international taxation the principle of national tax sovereignty had been challenged. But the OECD project was not intended to change the institutions of double tax avoidance themselves. It was established apart from the DTA regime and the connection between the two was deliberately left open. From an actor's perspective this is one of the advantages of layering: since two formally separated institutions are involved, the original rules and the layered ones do not necessarily 
have to be consistent. Ultimately, instead of changing the principles of the DTA regime directly, information exchange supplements the existing rules in the hope of keeping them viable despite pressure for change.

\section{Assessing the theory against the empirical evidence}

The empirical record shows that the endogenously created problem of under-taxation provides an impetus for reform of the established DTA institutions. But the need for reform has not resulted in fundamental change or a dismantling of the existing institutional setup. Instead, the specific institutional trajectory of the regime is characterized by institutional stability in the core principles, and subliminal but significant incremental change in the form of conversion and layering.

This institutional trajectory can be understood in terms of the strategic structures. The institutional solution to the coordination problem of avoiding double taxation engenders the asymmetric PD of under-taxation. As has been shown actors react to the functional necessities of trying to overcome the PD by attempting to reform the DTA regime. As the theory predicts, the efforts at reform are multilateral with the aim of including all or at least most states. This is evidenced by the fact that the OECD actively engaged in the diffusion of governments’ unilateral anti-avoidance strategies. It is further evidenced by the OECD project against harmful tax competition. Also, albeit with limited success, governments try to strengthen enforcement capabilities, e.g. by pressuring tax havens to exchange information. But, as expected, the DTA regime was not fully adapted to meet the challenge of undertaxation, and this for three main reasons.

First, there is self-enforcement deriving from the fact that DTA is a coordination game. Actors do not want to endanger the coordinating function of the established regime principles, so they act cautiously in their attempts to reform. Rule stretching in the area of CFC 
legislation and transfer pricing guidelines are telling illustrations for this, as is the strategy of layering the project on harmful tax practices on top of the existing DTA regime. In effect the self-enforcing process means that the DTA regime not only contributes to the constitution of tax competition but it also pre-structures the institutional reactions to tax competition.

Second, the incomplete adaptation of the DTA regime is also due to strong conflicts of interest in the asymmetric PD of tax competition. Big and small countries (tax havens) have conflicting interests and cannot reach full agreement; tax havens successfully block more ambitious efforts at curbing tax competition within the OECD project. The result, focussing only on bilateral information exchange, can be seen as a compromise solution which contains an implicit side payment to tax havens.

Third, this result is in line with the predictions on societal interests and the strength of their influence on national governments. Narrowing the scope of CFC rules and the US government's change of preference vis-à-vis the OECD project are relevant examples for the influence of corporate capital on governments. The new focus on information exchange is in line with the expectation that individual capital would not be able to prevent action against (illegal) tax evasion, whereas corporation's tax planning possibilities were not challenged. As predicted, labour representatives, who have generally shown little interest in international taxation matters, did not oppose these developments.

\section{ALTERNATIVE EXPLANATIONS}

How does this account fare compared to other explanations? In order to test the validity of my explanation I consider three potentially rival explanations. 


\section{$\underline{\text { National tax sovereignty renders effective international cooperation impossible }}$}

The bilateral and soft law nature of the DTA regime and its failure to establish effective cooperation against harmful tax competition is often ascribed to countries' desire to maintain their sovereignty (cf. e.g. Ring, 2008). While this claim is rarely spelled out in a fully developed account of the institutional design of international tax governance, it could be understood as a competitor to my explanation.

It is true that governments want to preserve tax sovereignty. And, the DTA regime was constructed in a sovereignty-preserving way, so that double taxation can be avoided by interface regulation. Governments cherish the flexibility of this setup which allows them to design their domestic tax laws independently of other countries. Nevertheless, as an explanation of institutional design and development, the desire to preserve sovereignty is incomplete. This becomes apparent when comparing reactions to double taxation on the one hand to reactions to under-taxation on the other. While governments preserve their tax sovereignty in avoiding double taxation, they are nevertheless willing—albeit grudgingly—to relinquish at least part of their formal sovereignty in the fight against tax evasion and avoidance. They agree to sharing tax information and increasing administrative cooperation. In line with my explanation, the extent to which governments manage to actually preserve their formal sovereignty depends on the functional requirements of the respective problem. While a sovereignty-preserving solution is viable in the coordination game of double tax avoidance, the asymmetric PD of under-taxation requires a sharing of tax sovereignty, in order for governments to achieve their policy goals.14 This shows that the concern over sovereignty is not the immovable mover of international tax governance (Rixen, 2008: 191-3). 


\section{$\underline{\text { Tax competition does not hurt big country governments }}$}

Some political scientists have shown that no race to the bottom in (general and corporate) tax revenues occurred in OECD countries (e.g. Swank, 2002; Garrett and Mitchell, 2001). Others have shown that taxes do not affect foreign direct investment (FDI) (Jensen, 2007). These scholars have concluded that governments retain sufficient policy autonomy to pursue their preferred policies. This suggests an alternative explanation for the fact that the double tax regime has changed little, namely, that big country governments had no reason to push harder for reform of global taxation rules.

Whether corporate tax revenue has indeed remained stable, if properly measured,15 is still a matter of debate. The majority of studies conclude that taxes impact FDI negatively (de Mooij and Ederveen, 2008). Nevertheless, the findings with respect to these two factors do indeed suggest that tax competition does not play an important role. But the focus on these factors is misleading and rests on a misguided understanding of the mechanisms of tax competition. It does not pay sufficient attention to the fact that governments actually had to implement reforms in order to prevent revenue losses. Governments were forced to lower statutory corporate tax rates (the decisive factor for the attraction of paper profits) and broaden the tax base (Ganghof, 2006; Genschel, 2002). They also had to shift the tax burden to consumption and labour (Loretz, 2008). Such reforms come at a real political cost.

The observations that revenue remains stable and FDI is not impacted cannot be the basis of a rival explanation because they in fact underscore my account. Precisely because the competition is mainly for paper profits (virtual tax competition), the elasticity of real investment to taxes is relatively low.16 Instead of showing that tax competition is no danger to governments' policy autonomy, the focus on revenue and FDI obscures the real dangers that governments face by ignoring the mechanisms of actual tax competition. 
The fact that big countries engage in efforts to reform the tax regime shows that they actually sense these dangers. Moreover, the fact that governments behave cautiously, distinguish between individual evasion and corporate avoidance and are at best moderately successful at reform can well be explained by the potential substitutability of virtual and real tax competition, interest constellations on the international level and the related domestic politics.

\section{Norms of appropriate behaviour prevented an effective solution}

While there is no constructivist account of the entire trajectory of global tax cooperation, Sharman (2006) addresses the failure of the OECD project on harmful tax practices. He argues that big countries were unable to effectively pressure small tax havens to behave as they wished because neither military coercion nor economic sanctions were in line with generally shared notions of appropriate behaviour among states. In particular, the OECD, whose authority derives from its status as an impartial expert bureaucracy devoted to the liberal market ideology could not convincingly argue against (tax) competition. This is plausible.

But are the norms of appropriate behaviour the best explanation for the failed campaign? Sharman himself acknowledges that in order to substantiate this, competing hypotheses have to be rejected. With respect to rationalist accounts, he argues that their two most important predictions do not hold. First, even though there is massive room for side payments because big countries would gain more from effectively curbing competition than tax havens lost and could thus easily compensate them, no such deal has been struck. Second, this failure to strike a deal can also not be explained by the capture of some big country governments by business interests. 
Both claims can be refuted. In light of the substitutability of virtual and real tax competition, the room for side payments is not as big as Sharman suggests. If big country governments manage to put tax havens out of business by preventing profit shifting, the result may be real tax competition, leaving governments less (or a potentially negative) surplus to compensate small countries. Even if some room for side payments remained, Sharman’s second claim would also have to be true to disprove the account proposed here. A full rebuttal requires detailed analysis of the available evidence, which space constraints preclude here. Suffice it to point out that the majority of international tax observers consider this claim to be misplaced and direct readers to appropriate counter evidence (e.g. Ring, 2008, 183-201; Easson, 2004, 1052-9). ${ }^{17}$ Consequently, my rationalist account cannot be rejected by the norm-based argument.

\section{CONCLUSION}

This article presented a history of international tax governance and offered a rationalist reconstruction of its trajectory. As an unintended consequence of its institutional setup, the tax regime, which originally only dealt with double tax avoidance, endogenously creates under-taxation. Despite this negative effect governments can only incrementally and partially adapt the regime. I have argued that we can explain this development by considering the strategic structures and the sequence in which the problems of double taxation and undertaxation appear. First, once they had agreed on double tax avoidance, a coordination game with a distributive conflict, governments did not want to endanger the solution they had institutionalized long before tax competition became virulent. Second, governments are unable to resolve the emergent asymmetric PD of under-taxation. This is because of (a) conflicts of interest among big and small country governments and (b) hesitance of big country governments to curb the shifting of paper profits, as a response to domestic political 
pressure from corporate capital. As a result, the institutional trajectory is characterized by the simultaneous occurrence of stability in the core principles and indirect and incremental changes of the rules in the form of rule stretching (i.e. conversion) and layering. The tax regime cannot effectively curb harmful tax competition.

Two implications of this account of international tax governance for IPE research more generally may be notable. First, it is a case study of the paradoxical strength of soft law. By general standards the DTA regime is weak because it rests on non-binding soft law. Despite this, the regime has lingered on even though there is an impetus for reform. The phenomenon of resilient soft law may also be at work in other issue areas of IPE and the theoretical mechanisms to which I refer may help to get a better grip on such instances.

Second, my account shows that, while the DTA regime is based on non-binding soft law, it nonetheless effectively governs actors' behaviour and has serious consequences. The DTA rules endogenously create and shape the structure of international tax competition and thus seriously constrain nation states' tax policy autonomy. Focussing on the rules of international double tax avoidance reveals the institutional foundation of double tax avoidance. This shows that the challenge of globalization to the nation state, which is often conceptualized as an exogenous pressure, is (often) endogenously produced by prior institutional choices on the international level. This insight is likely to apply to other issue areas and can only be demonstrated by following the advice of historical institutionalists to pay close attention to issues of sequence and timing. 


\section{ACKNOWLEDGMENTS}

For valuable comments and suggestions I thank Ilan Benshalom, Peter Dietsch, Steffen Ganghof, Tim Gemkow, Philipp Genschel, Monika Heupel, Markus Jachtenfuchs, Mary Kelley-Bibra, Ingo Rohlfing, Peter Schwarz, Susanne Uhl, Lora Viola, Bernhard Zangl, Michael Zürn, participants at the workshop ‘Tax Justice, Transparency and Accountability’ (3-4 July 2008, Essex University) organized by the Tax Justice Network and three anonymous reviewers as well as the editors of RIPE. Of course, all remaining errors are my own.

\section{NOTES}

${ }^{1}$ There is a rich body of legal literature on international taxation (see e.g. Avi-Yonah, 2006, and other references throughout the text). This literature rarely addresses questions of interest to political economists (but see e.g. Dagan, 2000; Picciotto, 1992). The only contributions from political science are Radaelli (1998), Webb (2001) and Rixen (2008, 2010).

${ }^{2}$ There is broad consensus in the literature that the two problems are accurately represented by the interest constellations derived in the following. On the strategic structure of under-taxation or tax competition, see e.g. Bucovetsky (1991), Deheeja/Genschel (1999), Holzinger (2005) and Basinger/Hallerberg (2004). The smaller body of literature on the strategic structure of DTA (e.g. Gresik, 2001; Davies, 2003) also supports the findings summarized here.

${ }^{3}$ Since every country has two choice variables, providing double tax relief or not, and levying source taxes or not, the situation cannot easily be depicted in a two-dimensional matrix. As shown in detail in Rixen (2008, 32-41), the overall structure corresponds to the well-known battle of the sexes game.

${ }^{4}$ In fact, it may be argued that the rules in most countries favour the interests of capital over national welfare, because most countries not only provide partial (deduction) but also full tax relief 
(credit or exemption). While according to more recent studies full relief maximizes national welfare, the conventional wisdom in public finance is that partial relief is more appropriate in this respect (Rixen, 2008, 32-41).

${ }^{5}$ Recent studies have suggested that preventing paper profit shifting not only runs counter to special interests but also reduces national welfare. However there remains considerable disagreement about this in the public finance literature (Dharmapala, 2008; Slemrod and Wilson, 2006).

${ }^{6}$ Belgium initiated a system of partial deductions in 1906 and has had a general deduction since 1919; the Netherlands had introduced a credit prior even to the US. Several Swiss Cantons operated deduction systems. Great Britain allowed a deduction, but only for income earned in the dominions (League of Nations, 1925: 11). Australia, New South Wales and South Africa employed an exemption system (Graetz and O'Hearh, 1997: 1046).

${ }^{7}$ The numbers of DTTs used throughout this paper come from a self-compiled database. For data sources see Rixen (2008: appendix).

${ }^{8}$ The UN MC accords greater weight to the source than to the residence principle and is thus better attuned to the interests of capital importing, developing countries.

${ }^{9}$ Tax havens have been subdivided into 'production havens', 'headquarter havens' (offer the incorporation in their territory regardless of where the shareholders reside), 'sham havens' (host financial intermediaries that are little more than an address for investment activity) and 'secrecy havens' (specialize in allowing personal income tax evasion by reinvesting funds that have been provided without the knowledge of authorities at home). Most real-world tax havens provide some mix of these functions (Eden and Kudrle, 2005).

${ }^{10}$ It is noteworthy that the technical experts argued the converse. Rather than seeing effective prevention of double taxation as a precondition for fighting evasion, they insisted that curbing international tax evasion would recover many tax revenues now foregone and consequently put states 
into a position where they could more willingly provide double tax relief to honest taxpayers (League of Nations, 1925: 28).

${ }^{11}$ The executive branch was also under pressure from Congress. Many senators would like to have seen the US push for fully fledged unitary taxation. However, at least since the confrontation between the UK and the US over California's system of formula apportionment, it was thought to be impossible to achieve consensus on this internationally. The Internal Revenue Service therefore rejected the demand (Radaelli, 1998).

${ }^{12}$ As anecdotal evidence consider some of the legislative measures the USA has introduced over the years labelled, for instance, the 'branch profits tax’ (1986), the 'earnings stripping rule’ belonging to the class of thin capitalization rules, the 'multiparty financing rules' (1995) belonging to the class of anti-treaty shopping provisions or the 'reverse hybrid rules' (1997). The list is far from exhaustive.

${ }^{13}$ http://www.oecd.org/document/7/0,3343,en_2649_33745_38312839_1_1_1_1,00.html (last accessed 21 December 2009)

${ }^{14}$ In fact, by sharing their de jure sovereignty, they can gain de facto sovereignty over their substantive tax policy goals (Rixen, 2008: 200-3).

${ }^{15}$ Most importantly, controlling for the number of incorporated companies and the level of profitability, may lead to different results (Clausing, 2007; Loretz, 2008). In fact, the increase in the number of incorporated companies may well be one of the effects of tax competition for paper profits (Bucovetsky and Haufler, 2008).

${ }^{16}$ In their meta study, deMooij and Ederveen $(2008,695)$ find that the semi-elasticity of FDI to tax rate changes is between -0.4 to -0.65 , whereas that for reported profits is -1.2 .

${ }^{17}$ Sharman actually discusses these domestic lobbying efforts in the USA and rejects the notion that they reflect the influence of business interests on policy formulation. He bases this claim on the fact that the most vocal and visible opponent, the Center for Freedom and Prosperity (CFP), was only 
a very small "think tank" with limited resources. Given that the CFP is funded by financial services firms, maintains close connections to important officials and has met with government representatives, this conclusion is unconvincing (Giridharadas, 2001; Cloud, 2001).

\section{NOTES ON CONTRIBUTOR}

Dr. Thomas Rixen, political scientist and economist, is a senior fellow at the Social Science Research Center Berlin. His research interests include international and comparative political economy, public finance and institutional theory. URL:

http://www.wzb.eu/zkd/tki/people/rixen.en.htm

\section{REFERENCES}

Arnold, Brian J. and McIntyre, Michael J. (1995). International Tax Primer. Den Haag, Kluwer Law International.

Avi-Yonah, Reuven S. (2006). International Tax as International Law: An Analysis of the International Tax Regime. New York, Cambridge University Press.

Basinger, Scott J. and Hallerberg, Mark (2004). "Remodeling the Competition for Capital: How Domestic Politics Erases the Race to the Bottom." American Political Science Review 98(2): 261-276.

Bird, Richard M. and Wilkie, J. Scott (2000). Source- vs. Residence-Based Taxation in the European Union: The Wrong Question? Taxing Capital Income in the European Union. Issues and Options for Reform. Cnossen, S. (Ed.). New York, Oxford University Press: 78-109. 
Blyth, Mark (2007). "Powering, Puzzling, or Persuading? The Mechanisms of Building Institutional Orders." International Studies Quarterly 51(4): 761-777.

Bordo, Michael D.,Eichengreen, Barry and Irwin, Douglas A. (1999). Is Globalization Today Really Different Than Hundred Years Ago? Cambridge, National Bureau of Economic Research Working Paper No. 7195.

Broome, André and Seabrooke, Leonard (2007). "Seeing Like the IMF: Institutional Change in Small Open Economies." Review of International Political Economy 14(4): 576-601.

Bucovetsky, Sam (1991). "Asymmetric Tax Competition." Journal of Urban Economics 30(2): 167-181.

Bucovetsky, Sam and Haufler, Andreas (2008). "Tax Competition when Firms Choose their Organizational Form: Should Tax Loopholes for Multinationals be Closed?" Journal of International Economics 74(1): 188-201.

Carroll, Mitchell B. (1939). Prevention of International Double Taxation and Fiscal Evasion. Two Decades of Progress under the League of Nations. Geneva, Series of League of Nations Publications II. Economic and Financial 1939.II.A.8.

Célestin, Lindsay C. (2000). The Formulary Approach to the Taxation of Transnational Corporations: A Realistic Alternative? University of Sidney, PhD Thesis.

Clausing, Kimberly A. (2007). "Corporate Tax Revenues in OECD Countries." International Tax and Public Finance 14(2): 115-133.

Cloud, David S. (2001). Virginian Fights for International Tax Havens_Lobbyist Finds Bush Receptive to Ideas Clinton Rejected. The Wall Street Journal. July 30, 2001: A20. 
Council of Europe and OECD (2003). Joint Council of Europe/OECD Convention on Mutual Administrative Assistance in Tax Matters.

Dagan, Tsilly (2000). "The Tax Treaties Myth." New York University Journal of International Law \& Politics 32 (4): 939-996.

Davies, Ronald B. (2003). "The OECD Model Tax Treaty: Tax Competition and Two-Way Capital Flows." International Economic Review 44(2): 725-753.

de Mooij, Ruud A. and Ederveen, Sjef (2008). "Corporate Tax Elasticities: A Reader’s Guide to Empirical Findings." Oxford Review of Economic Policy 24(4): 680-697.

Dehejia, Vivek H. and Genschel, Philipp (1999). "Tax Competition in the European Union." Politics \& Society 27(3): 403-430.

Dharmapala, Dhammika (2008). "What Problems and Opportunities Are Created by Tax Havens?" Oxford Review of Economic Policy 24(4): 661-679.

Easson, Alex (2004). "Harmful Tax Competition: An Evaluation of the OECD Initiative." Tax Notes International 34(June 7): 1037-1077.

Eden, Lorraine (1998). Taxing Multinationals: Transfer Pricing and Corporate Income Taxation in North America. Toronto, University of Toronto Press.

Eden, Lorraine and Kudrle, Robert T. (2005). "Tax Havens: Renegade States in the International Tax Regime." Law \& Policy 27(1): 100-127.

Engel, Keith (2001). "Tax Neutrality to the Left, International Competitiveness to the Right, Stuck in the Middle with Subpart F." Texas Law Review 79(6): 1525-1607.

Fioretos, Orfeo (2007). International Political Development: Toward a New Historic Turn in International Relations? Temple University, Unpublished Manuscript. 
Ganghof, Steffen (2006). The Politics of Income Taxation. A Comparative Analysis of Advanced Industrial Countries. Colchester, ECPR Press.

Garrett, Geoffrey and Mitchell, Deborah (2001). "Globalization, Government Spending and Taxation in the OECD." European Journal of Political Research 39(2): 145-177.

Genschel, Philipp (2002). "Globalization, Tax Competition and the Welfare State." Politics \& Society 30(2): 244-274.

Giridharadas, Anand (2001). Saved Havens. the Treasury coddles Tax Cheats. The New Republic. August 27, 2001.

Graetz, Michael J. (2001). "Taxing International Income: Inadequate Principles, Outdated Concepts and Unsatisfactory Policies." Tax Law Review 54(3): 261-336.

Graetz, Michael J. (2003). Foundations of International Income Taxation. New York, Foundation Press.

Graetz, Michael J. and O'Hearh, Michael M. (1997). "The 'Original Intent' of US International Taxation." Duke Law Journal 46(5): 1021-1109.

Gresik, Thomas A. (2001). "The Taxing Task of Taxing Transnationals." Journal of Economic Literature 39(3): 800-838.

Hampton, Mark P. and Christensen, John (2003). A Provocative Dependence? The Global Financial System and Small Island Tax Havens. Global Governance, Conflict and Resistance. Cochrane, F., R. Duffy and J. Selby (Ed.). Basingstoke, Palgrave Macmillan: 194-215.

Hays, Jude C. (2003). "Globalization and Capital Taxation in Consensus and Majoritarian Democracies." World Politics 56(1): 79-113. 
Helleiner, Eric (1994). States and the Reemergence of Global Finance. From Bretton Woods to the 1990s. Ithaca, Cornell University Press.

Hines, James R. (2005). Do Tax Havens Flourish? Tax Policy and the Economy, Volume 19. Poterba, J. M. (Ed.). Cambridge, MIT Press: 65-100.

Holzinger, Katharina (2005). "Tax Competition and Tax Cooperation in the EU. The Case of Savings Taxation." Rationality and Society 17(4): 475-510.

Jensen, Nathan M. (2007). Fiscal Policy and the Firm: Do Low Corporate Tax Rates Attract Multinational Corporations? Manuscript. $\underline{\text { http://ssrn.com/abstract=955713. }}$.

Keen, Michael (2001). "Preferential Regimes can make Tax Competition Less Harmful." National Tax Journal 54(4): 757-762.

Koremenos, Barbara,Lipson, Charles and Snidal, Duncan (2001). "The Rational Design of International Institutions." International Organization 55(4): 761-799.

Krasner, Stephen D. (1991). "Global Communications and National Power. Life on the Pareto Frontier." World Politics 43(3): 336-366.

Langbein, Stanley I. (1986). "The Unitary Method and the Myth of Arm's Length." Tax Notes 30 (February 17): 625-681.

League of Nations (1923). Report on Double Taxation. Submitted to the Financial Committee by Professors Bruins, Einaudi, Seligman and Sir Josiah Stamp. Geneva, League of Nations, E.F.S.73.F.19.

League of Nations (1925). Double Taxation and Tax Evasion. Report and Resolutions submitted by the Technical Experts to the Financial Committee of the League of Nations. Geneva, League of Nations, F. 212. 
League of Nations (1927). Double Taxation and Tax Evasion. Report Presented by the Committee of Technical Experts on Double Taxation and Tax Evasion. Geneva, League of Nations, C. 216. M 85. 1927 II.

League of Nations (1928). Double Taxation and Fiscal Evasion. General Meeting of Government Experts. October 1928. Geneva, League of Nations, C.495.M.147.1928.II.

League of Nations (1933). Taxation of Foreign and National Enterprises, Vol. II and III, and Methods of Allocating Taxable Income, Vol. IV. Geneva, League of Nations, C.425.M.217 1933 II A 18.

Li, Jinyan (2003). International Taxation in the Age of Electronic Commerce: A Comparative Study. Toronto, Canadian Tax Foundation.

Loretz, Simon (2008). "Corporate Taxation in the OECD in a wider Context." Oxford Review of Economic Policy 24(4): 639-660.

Musgrave, Peggy B. (2006). Combining Fiscal Sovereignty and Coordination. National Taxation in a Globalizing World. The New Public Finance. Responding to Global Challenges. Kaul, I. and P. Conceicao (Ed.). Oxford, Oxford University Press: 167-193.

O'Neill, Paul H. (2001). Confronting OECD’s Notions on Taxation. Washington Times. May 10.

OECD (1998). Harmful Tax Competition. An Emerging Global Issue. Paris, OECD.

OECD (2001). The OECD's Project on Harmful Tax Practices: The 2001 Progress Report. Paris, OECD.

OECD (2002). Agreement on Exchange of Information on Tax Matters. Paris, OECD. 
OECD (2004). The OECD's Project on Harmful Tax Practices: The 2004 Progress Report. Paris, OECD.

OECD (2008). Model Tax Convention on Income and on Capital. Electronic Version. Paris, OECD.

OECD (2009a). Revenue Statistics 1965-2008. Paris, OECD.

OECD (2009b). Transfer Pricing Guidelines for Multinational Enterprises and Tax Administrations. Paris, OECD.

Olson, Mancur (1965). The Logic of Collective Action. Public Goods and the Theory of Groups. Cambridge, Harvard University Press.

Palan, Ronen (2003). The Offshore World. Sovereign Markets, Virtual Places, and Nomad Millionaires. Ithaca, Cornell University Press.

Picciotto, Sol (1992). International Business Taxation. A Study in the Internationalization of Business Regulation. New York, Quorum.

Pierson, Paul (2004). Politics in Time. History, Institutions, and Social Analysis. Princeton, Princeton University Press.

Radaelli, Claudio M. (1998). "Game Theory and Institutional Entrepreneurship: Transfer Pricing and the Search for Coordination in International Tax Policy." Policy Studies Journal 26(4): 603-619.

Ring, Diane M. (2008). "What's at Stake in the Sovereignty Debate? International Tax and the Nation-State." Virginia Journal of International Law 49(1): 155-233. 
Rixen, Thomas (2007). Taxation and Cooperation: International Action Against Harmful Tax Competition. Globalization. State of the Art and Perspectives. Schirm, S. A. (Ed.). London, Routledge: 61-80.

Rixen, Thomas (2008). The Political Economy of International Tax Governance. Basingstoke, Palgrave/Macmillan.

Rixen, Thomas (2010). "Why Bilateralism (and Multilateralism)? The Political Economy of Avoiding International Double Taxation." European Journal of International Relations. in print.

Sandler, Daniel (1994). Pushing the Boundaries: The Interaction Between Tax Treaties and Controlled Foreign Company Legislation. London, Institute of Taxation.

Schwarz, Peter (2007). "Does Capital Mobility Reduce the Corporate-Labor Tax Ratio?" Public Choice 130(3-4): 363-380.

Sharman, Jason C. (2006). Havens in a Storm: The Struggle for Global Tax Regulation. Ithaca, Cornell University Press.

Slemrod, Joel and Wilson, John D. (2006). Tax Competition with Parasitic Tax Havens. NBER Working Paper No. 12225.

Snidal, Duncan (1985). "Coordination versus Prisoner's Dilemma: Implications for International Cooperation and Regimes." American Political Science Review 79(4): 923942.

Streeck, Wolfgang and Thelen, Kathleen (2005). Institutional Change in Advanced Political Economics. Beyond Continuity. Institutional Change in Advanced Political Economics. Streeck, W. and K. Thelen (Ed.). Oxford, Oxford University Press: 1-39. 
Sullivan, Martin A. (2007). "Lessons from the Last War on Tax Havens." Tax Notes 116 (July 30): 327-337.

Swank, Duane (2002). Global Capital, Political Institutions, and Policy Change in Developed Welfare States. Cambridge, Cambridge University Press.

Swank, Duane and Steinmo, Sven (2002). "The New Political Economy of Taxation in Advanced Capitalist Democracies." American Journal of Political Science 46(3): 642655.

Tax Justice Network (TJN) (2005). Tax Us if You Can. The True Story of a Global Failure. http://www.taxjustice.net/cms/upload/pdf/tuiyc___eng___web_file.pdf (accessed 29 May 2006).

Thelen, Kathleen (2003). How Institutions Evolve. Insights from Comparative Historical Analysis. Comparative Historical Analysis in the Social Sciences. Mahoney, J. and D. Rueschemeyer (Ed.). Cambridge, Cambridge University Press: 208-240.

United Nations (2001). Model Double Taxation Convention between Developed and Developing Countries. New York, United Nations Publications.

United Nations (various years). World Investment Report for the years 1992, 1998 and 2007. http://www.unctad.org/Templates/Page.asp?intItemID=1485\&lang=1 (accessed 10 July 2007).

Vann, Richard J. (1991). "A Model Tax Treaty for the Asian-Pacific Region? (Part I and II)." Bulletin for International Fiscal Documentation 45(3 and 4): 99-111 and 151-163.

Wang, Ke Chin (1945). "International Double Taxation of Income: Relief through International Agreement 1921-1945." Harvard Law Review 59(1): 73-116. 
Webb, Michael C. (2001). Reconciling Practice and Structure: US Regulation of Transfer Pricing by Transnational Firms. Structure and Agency in International Capital Mobility. Sinclair, T. J. and K. P. Thomas (Ed.). New York, Palgrave: 129-152.

Webb, Michael C. (2004). "Defining the Boundaries of Legitimate State Practice. Norms, Transnational Actors and the OECD's Project on Harmful Tax Competition." Review of International Political Economy 11(4): 787-827.

Webber, Carolyn and Wildavsky, Aaron (1986). A History of Taxation and Expenditure in the Western World. New York, Simon and Schuster.

Zürn, Michael,Binder, Martin,Ecker-Erhardt, Matthias and Radtke, Katrin (2007). "Politische Ordnungsbildung wider Willen." Zeitschrift für Internationale Beziehungen 14(1): 129164. 